\title{
Revealing Tells, Bawdy and Otherwise, in Coriolanus
}

\begin{abstract}
By John Maune*
The title character of Shakespeare's late tragedy Coriolanus does not easily endear himself to his own citizens or we the viewing audience. Coriolanus is seen by many as a political play, but the main character is too naive to be strange or political. Similar to fellow turncoat Roman Titus Andronicus, he is a politically inept soldier surrounded by those more versed in swaying with the times as is the wont of true two-faced politicians. Coriolanus vents his thoughts as they come-more three-year old than statesman. He is always a hair trigger removed from erupting with a tantrum of strident invective. Scabs, braying dogs, and fetid corpses are a few of the images he dredges up to vent his spleen on the commoners. However, the other characters in play can be said to be more deserving on our condemnation than Coriolanus, as their curses and carnal imagery are far more depraved, even though used for a wide range of purposes spanning praise to ridicule. This paper will examine such examples, and present the case that Shakespeare's Coriolanus is not Olivier's "son of a so-and-so," but nearer Bradley's "noble, even a lovable, being."
\end{abstract}

\section{Introduction}

The title character of Shakespeare's late tragedy Coriolanus does not easily endear himself to his own citizens or to us the viewing audience. "Coriolanus has absolutely no good attribute except physical courage, which he shares with most men and many animals, ${ }^{1 "}$ and is "the splendid oaf who has never come to maturity" and "a proud man who assumes the right to despise persons of a lesser breed."2 Olivier thought him "a very straightforward, reactionary son of a so-and-so" whose "thoughts are not deep" and "he is a patrician first and foremost, and that his pride is of the nature that he is too proud even to accept praise."3 Ralph Fiennes said he "just became obsessed with this man [Coriolanus]," and after playing Coriolanus on stage produced, directed, and stared in a movie version of Coriolanus, though "He's one of the hardest characters to like, I think." ${ }^{4}$ Hardly the stuff dreams are made on. Knight, ${ }^{5}$ as almost everyone before and since, found Coriolanus full of

*Professor, Hokusei Gakuen University, Japan.

1. Wyndham Lewis, The Lion and the Fox (London: Grant Richards, 1927), 241.

2. John Palmer, Political Characters of Shakespeare (London: Macmillan, 1961), [6th ed.], $297 \& 309$.

3. Judith Cook, Shakespeare's Players (London: Harrap Limited, 1985), [2nd ed.], 94.

4. Julian Curry, Shakespeare on Stage (London: Nick Hern Books, 2010), 38-39.

5. George Knight, The imperial theme: further interpretations of Shakespeare's tragedies including the Roman plays (London: Methuen, 1954), 160-163. 
aristocratic haughtiness and pride, but virtue too: "Grim as he is in his warring and pride, we must observe, too, his essential virtue." Bradley was even more forgiving, "the pride and self-will of Coriolanus, though terrible in bulk, are scarcely so in quality; there is nothing base in them, and the huge creature whom they destroy is a noble, even a lovable, being."6 However, as repellent as many find him, Goddard saw him as a continuation of Shakespeare's delight from Hamlet on "in creating incorrigible truth-tellers who discomfort and undo the hypocrites and knaves: Emilia (at the end), Kent, Cordelia herself, Timon, Paulina, even Thersites and Apemantus, for whom - who can doubt it?-Shakespeare had more respect than for Osric or Parolles. Coriolanus is a pre-eminent member of this group. Lear's youngest daughter and the conqueror of Corioli have much in common."7

The play, like its eponymous character, is hard to categorize. This has lead to a list that would make Polonius proud: for Dryden a great Roman history, for Shaw a comedy, ${ }^{9}$ for Campbell a satire, ${ }^{10}$ for Hellpern a black comedy, ${ }^{11}$ for Burke a grotesque tragedy, ${ }^{12}$ and, simply, a tragedy for Swinburne. ${ }^{13}$ Coriolanus and his hubris would seem to put the play in the classic tragedy form, but Shakespeare was ever one to stray from tried and true forms, even mockingly at times.

The play is politically charged, however it has been used to support a wide range of extremes: pro- and anti-Fascist, Hitler's Nazis, and Marx's proletariat. ${ }^{14}$ Coleridge deemed the play politically impartial, as did Ripleyindeterminate and uncommitted - which has allowed directors and actors to sway the production to favor whatever faction they desire. ${ }^{15}$ Brecht recast the

6. Andrew Cecil Bradley, Shakespearean Tragedy: Lectures on Hamlet, Othello, King Lear, Macbeth (London: Macmillan), [2nd ed.], 83.

7. Harold Goddard, The Meaning of Shakespeare, vol. 2 (Chicago: Chicago University Press, 1960), [2nd ed.], 210, 219-225.

8. John Dennis, The Critical Works of John Dennis, ed. Edward Niles Hooker (Baltimore: Johns Hopkins Press, 1943), 2: 164.

9. George Bernard Shaw, Man and Superman (Cambridge, Mass.: The University Press, 1903).

10. Oscar James Campbell, Shakespeare's Satire (New York: Gordian Press, 1971), [2nd ed.], 199.

11. John Hellpern, "Shakespeare's Least-Loved Play; But This Coriolanus Stands Apart," Observer, last modified February 28, 2005, goo.gl/Z6UpBF.

12. Kenneth Burke, "Coriolanus - and the Delights of Faction," The Hudson Review 19, no. 2 (1966).

13. Algernon Charles Swinburne, A study of Shakespeare (London: Chatto \& Windus, 1880), [2nd ed.], 188.

14. Curry, Shakespeare on Stage.

15. John Ripley, Coriolanus on Stage in England and America, 1609-1994 (Cranbury, N.J.: Associated University Presses, 1998), 56 \& 337. 
commoners and tribunes as Marxist heroes in his Coriolanus adaptation, which caused Gunter Grass to write a play parodying Brecht's betrayal of Shakespeare as portraying the scheming tribunes as heroes is untenable. ${ }^{16}$

The rude and deprecatory language that Coriolanus uses to stridently accost the commoners and their tribunes clearly indicates the contempt in which he holds them, but he is honest. ${ }^{17}$ His mother Volumnia preaches lofty virtues, though actually following them is another matter. Menenius uses grotesque imagery to put down the commoners and tribunes, but he always does so in an avuncular and political-calculating-fashion. The tribunes are asses, the commoners spineless, and Aufidius petty. Coriolanus's faults are exposed as he does nothing to hide them, while others show their true thoughts only when expedient.

\section{Discussion}

\section{Coriolanus}

What's in a name? For Shakespeare, plenty. Goddard points out that Shakespeare enjoyed punning when naming characters; the core "Cor," Latin for heart, relation between Cordelia and Coriolanus [Corin too?] and their vehement adherence to their own truths is not at all far-fetched..$^{18}$ Hunt zeroed in on a different tract for the hero's name-Coriolanus-which highlights the body politic and lower body or backward connotation inherent in the playCoriolanus was like waste that needed to be, and subsequently was, expelled. ${ }^{19}$ Coriolanus himself does little to dispel his name's "anus" ending; his first words uttered in the play are directed toward commoners rioting over lack of food exemplify the antagonistic condescending voice Coriolanus uses for the commoners that he maintains throughout the play (Coriolanus quotes from Shakespeare)..$^{20}$

\subsubsection{3-155}

Marcius - Thanks. What's the matter, you dissentious rogues,

That, rubbing the poor itch of your opinion,

Make yourselves scabs?

16. John Gross, After Shakespeare, ed. John Gross (Oxford: Oxford University Press, 2002), 296.

17. Goddard, The Meaning of Shakespeare.

18. Ibid.

19. Maurice Hunt, "The Backward Voice of Coriolanus," Shakespeare Studies 32 (2004).

20. William Shakespeare, Coriolanus, ed. Kenneth Deighton (London: Macmillan, 1900), Shakespeare Online, accessed February 20, 2010, goo.gl/xJo6Q4. 
His very next lines (1.1.157-177) are more cutting where he uses deragatory imagery that portrays the commoners as fickle cowards.

\subsubsection{3-175}

Marcius -With every minute you do change a mind,

And call him noble that was now your hate,

Him vile that was your garland.

His demeaning imagery and repeatedly voiced desire to hang the protesters does not endear him to the people, or us for that matter, but the commoners are, and will again prove to be, changelings, and play their part in his eventual banishment from Rome.

His next tirade comes against his own troops who hadn't been as valiant as desired while fighting the Volscians.

\subsubsection{8-44}

Marcius - All the contagion of the south light on you,

You shames of Rome! you herd of--Boils and plagues

Plaster you o'er, that you may be abhorr'd

Further than seen and one infect another

Against the wind a mile! You souls of geese,

That bear the shapes of men, how have you run

From slaves that apes would beat! Pluto and hell!

Saint Crispin this was not. His abusive tirade does not incline his soldiers to join Marcius in attacking the enemy city of Corioli while its gates are open. They watch somewhat disinterestedly as Coriolanus rushes in and the gates close behind him - he is alone in the hostile city. They assume he will be cut to shreds, but care not. Can we blame them?

Coriolanus of course not only survives but single-handedly wins the city. These heroics, after the battles are done, he is offered the lion's share of the spoils: he is content to take the common share. Thus, he is forcibly given the appellation Coriolanus: he is not enthused.

He has no time to recover or tend to his wounds when he shows another side of his invective. This time, however, he deeply respects the man he is confronting; Tullus Aufidius is his bitter sworn enemy. He uses foul imagery for railing against the commoners, but saves his most telling denunciation for Aufidius, though it sounds rather infantile-promise-breaker (1.8.2). This provides insight into his rage against the commoners: they do not stay true to their words. Honor and keeping one's word for Coriolanus is a way of lifenot something to bargain with.

His name is put forward for the consulship, but he must sue for the voices of the commoners. They grant him their support, only to renege on their 
promises making them monstrous members which they specifically wanted to avoid (2.3.3-12, \& Maune $\left.{ }^{21}\right)$. Coriolanus then insults the tribunes with a string of provocative questions.

\subsubsection{2-47}

Coriolanus - Are these your herd?

Must these have voices, that can yield them now

And straight disclaim their tongues? What are

your offices?

You being their mouths, why rule you not their teeth?

Have you not set them on?

Again, however confrontational the tone, Coriolanus - as when he called the commoners fickle-is right: the tribunes have "goaded" (2.3.283) the commoners on. He berates and insults the tribunes with increasing disgust until close to violence.

\subsubsection{8}

Coriolanus - Hence, old goat!

\subsubsection{1-222}

Coriolanus - Hence, rotten thing! or I shall shake thy bones

Out of thy garments.

He is advised by his mother that he must-as humble as the ripest mulberry-beg the commoners forgiveness for his outbursts-his knee bussing the stones. Do that to become consul. He listens to what his mother, Menenius, and Cominius say to him, and agrees, "Well, I must do't". He then likens himself to a range of demeaning images: harlot, eunuch, virgin, baby, knave, beggar, and crying schoolboy.

\subsubsection{3-146}

Coriolanus - I will not do't,

Lest I surcease to honour mine own truth And by my body's action teach my mind

A most inherent baseness.

Volumnia has shown her true colors and lost the confidence of her son: similar to when the nurse tells Juliet to marry Paris though already married to Romeo. Volumnia has ruled her son his whole life, but her advice to be "false to

21. John Maune, "Topsy-Turvy and Other Carnivalesque Aspects in Coriolanus," Athens Journal of Philology 3, no. 1 (2016). 
his nature" (3.2.17) when expedient leads to his break from her council. Independence follows.

Coriolanus, in perhaps the most humorous lines in the play, says he will answer the people mildly, yet maintain his honor. When he meets the tribunes and people to answer to their allegations, he is mild for a few brief sentences, but they try to "put him to choler straight" knowing that "once chafed, he cannot be rein'd again to temperance" so they can then "break his neck" (3.3.33-38). The tribunes now accuse him of being a traitor with tyrannical aims; his mildness is undone by the one word - traitor (3.3.86-92).

His tirade is not indicative of a humble man pensively holding his hat looking to restore his public image. His outrage continues and he is summarily banished. His scorn culminates in his last words uttered in Rome-a tirade in which his feelings toward the commoners are clearly presented.

\subsubsection{7-162}

Coriolanus - You common cry of curs! whose breath I hate

As reek o' the rotten fens, whose loves I prize

As the dead carcasses of unburied men

That do corrupt my air, I banish you;

And here remain with your uncertainty!

Let every feeble rumour shake your hearts!

Your enemies, with nodding of their plumes,

Fan you into despair! Have the power still

To banish your defenders; till at length

Your ignorance, which finds not till it feels,

Making not reservation of yourselves,

Still your own foes, deliver you as most

Abated captives to some nation

That won you without blows! Despising,

For you, the city, thus I turn my back:

There is a world elsewhere.

The second half finds a more subdued Coriolanus whose only outburst comes at the end of the drama. Aufidius, as the tribunes had done earlier, tries to ignite Coriolanus's anger by calling him a traitor to the assembled Volscian nobles. It fails. Aufidius tries again by alluding to his honorific nameCoriolanus-earned at mortal cost to the Volscians. It fails. Aufidius then calls him a boy of tears - the fuse has been lit-game over. Coriolanus proceeds to talk calmly with the lords, but his smouldering anger crescendos as he enacts Shakespeare's Roman version of suicide by cop-suicide by mob-when he eggs on the gathering to cut him to pieces. ${ }^{22}$

22. Ibid. 


\section{Volumnia}

The influence of Coriolanus's mother Volumnia is fertile ground for voluminous critical speculation. ${ }^{23,24}$ Her influence on her son is well knownone of the rebellious commoners in the very first scene suggests that Coriolanus acts to please his mother (1.1.32). Her character is harsh in the extreme and when she says to her obstinate son, "Thy valiantness was mine, thou suck'dst it from me, But owe thy pride thyself." (3.2.153-154). We believe her. However, upon more reflection it is obvious that she is disingenuously confusing the issue trying to manipulate her son saying she had all to do with his valiantness, and nothing to do with his pride. She callously manipulates her son to pursue her own forbidden, by her gender, political machinations.

The importance of first impressions on the stage was not lost on Shakespeare. Volumnia and Virgilia first appear on low stools sewing-a quaint domestic scene, all the better to contrast with Volumnia's soon to be apparent hyper-machismo. Her masculine nature is juxtaposed similarly to Virgilia's stereotypical femininity. ${ }^{25}$ Volumnia's first words are spoken evenly enough, but the imagery is incestuous and perversely carnal.

\subsection{1-18}

Volumnia - I pray you, daughter, sing; or express yourself in a more comfortable sort: if my son were my husband, I should freelier rejoice in that absence wherein he won honour than in the embracements of his bed where he would show most love. When yet he was but tender-bodied and the only son of my womb, when youth with comeliness plucked all gaze his way, when for a day of kings' entreaties a mother should not sell him an hour from her beholding, I, considering how honour would become such a person. that it was no better than picture-like to hang by the wall, if renown made it not stir, was pleased to let him seek danger where he was like to find fame. To a cruel war I sent him; from whence he returned, his brows bound with oak. I tell thee, daughter, I sprang not more in joy at first hearing he was a man-child than now in first seeing he had proved himself a man.

23. Rufus Putney, "Volumnia," in Twentieth Century Interpretations of Coriolanus, ed. James Phillips (London: Prentice Hall, 1970), [1st ed.], 104-105.

24. Ripley, Coriolanus on Stage in England, 56 \& 337.

25. Robert Humphrey, "Fatherly Mothering: Masculine Volumnia, a Martial Political Woman," The Artifice, last modified April 9, 2014, goo.gl/RrgUUV. 
Other characters also use awkward sexually charged images to express passionate admiration for virtues. Coriolanus is quite pumped after his fighting in Corioli; he hugs Cominius likening it to cuddling during the afterglow following coupling with his wife Virgilia (1.6.39-42). Aufidius uses similar imagery, but even more passionate, when he accepts Coriolanus's offer to serve him. Aufidius hugs Coriolanus with talk of his grained ash and the anvil of his sword-pointed intercourse. Joining with Coriolanus moves Aufidius's heart more than first seeing his wedded mistress, and he has had a recurring dream.

\subsubsection{5-129 [104-139]}

Aufidius - I have nightly since

Dreamt of encounters 'twixt thyself and me;

We have been down together in my sleep,

Unbuckling helms, fisting each other's throat,

And waked half dead with nothing.

These men respect each other and express it, like Volumnia, in sexual images outside the standard norms that go beyond warm and fuzzy to unsettling and creepy. The only moments that seem tender and pure-not foul of center, and sublime for a man afraid of words-involve Coriolanus speaking to Virgilia (2.1.175-179, \& 5.3.44-56). Menenius is even more vulgar with his long-foul-winded imagery, though done smilingly.

Volumnia then explains that she would rather her sons die nobly than live voluptuously (1.3.20-25)-esteemed in Roman matriarchs, if not maternally appealing. The prose and needlework continue as does Volumnia.

\subsubsection{6-41}

Volumnia - Away, you fool! it more becomes a man

Than gilt his trophy: the breasts of Hecuba,

When she did suckle Hector, look'd not lovelier

Than Hector's forehead when it spit forth blood

At Grecian sword, contemning. Tell Valeria,

We are fit to bid her welcome.

We see Volumnia sewing placidly with her son's wife imagining copulating with her son, his tender/comely youth-again smacking of incestuous undertones, Hecuba suckling Hector-Volumnia suckling her Marcius, and blood spitting from a cleaved forehead. This is done in praise, not at all in anger. Her images are incestuous, carnal, and grotesque: no inklings of love. It is no wonder that so many critics see her as responsible for her son's asocial manner. 
Throughout the play Volumnia shows anger, but never fully succumbs to rage. She aptly states that she has "a brain that leads her use anger to better vantage" (3.2.38-39). Lots of her anger seems to be put on so she can deftly push her son's all too easily activated buttons - it also seems she is enjoying herself at Virgilia's expense when she talks of gashes and blood. Following her son's banishment, she is furious with the tribunes, but she disparages them in a relatively under-control fashion lacking the passion so prevalent in her son. She is ever politically calculating.

Volumnia has loaded Coriolanus "with precepts that would make invincible the heart that conn'd them" (4.1.9-11). She worked much on method, but forgot to instill any importance to her desired goals: power and fame. She falsely assumed that her son, or anyone for that matter, would of course seek greater power and stature given the opportunity. Coriolanus many times directly says becoming consul is not something he cherishes (2.1.208-210, 2.3.112-124, \& 3.1.65-67): he would not even say "Good morrow" to the people if it would secure him the position (3.3.110-116). Volumnia built a Mars-like warrior, but with teachings too absolute.

\section{Menenius}

In the opening scene when the demonstrating commoners praise Menenius as he enters - "worthy; one that hath always loved the people," and "honest enough" (1.1.43-45) - we should take their words with a grain of salt. Menenius is the consummate politician, which is far from a compliment. When he addresses the people he is always close to fawning with his projected familiar good will. His second lines to the people illustrate this.

\subsubsection{3-54}

Menenius - Why, masters, my good friends, mine honest neighbors, Will you undo yourselves?

He is adept at using humor (2.1.44) so that he can mock, yet still enjoy the people's good opinion. The following words by Coriolanus to the people seem to relate specifically to Menenius, though Coriolanus is mocking counterfeiting politicians, as well as himself and the people.

\subsubsection{5-105}

Coriolanus - You should account me the more virtuous that I have not been common in my love. I will, sir, flatter my sworn brother, the people, to earn a dearer estimation of them; 'tis a condition they account gentle: and since the wisdom of their choice is rather to have my hat than my heart, I will practise 
the insinuating nod and be off to them most counterfeitly; that is, sir, I will counterfeit the bewitchment of some popular man and give it bountiful to the desirers. Therefore, beseech you, I may be consul.

Menenius's encounter with the tribunes (2.1) is perhaps more telling and entertaining than his fable of the belly in the opening scene. He accuses them of being infant-like, unmeriting, proud, violent, testy fools, but, true to form, the exchange seems amicable enough. He goes on to imply that the tribune's are talking asses ${ }^{26}$-not like Bottom in A Midsummer Night's Dream, but bottoms that expel waste.

\subsubsection{4-59}

Menenius - I can't say your worships have

delivered the matter well, when I find the ass in compound with the major part of your syllables: and though I must be content to bear with those that say you are reverend grave men, yet they lie deadly that tell you you have good faces.

All they say is asinine, and their faces are butt ugly too; this causes no reaction at all. Menenius also says he "converses more with the buttock of the night than with the forehead of the morning" (2.1.49-51) which for Hunt was again setting up anal or backward voice, though possibly Menenius is stating that he is partial to doggy-style sex as opposed to fellatio, keeping with his backside references. ${ }^{27} \mathrm{He}$ further disparages the tribunes in scatological fashionthey are full of shit.

\subsubsection{1-76}

Menenius - if you chance to be

pinched with the colic, you make faces like

mummers; set up the bloody flag against all

patience; and, in roaring for a chamber-pot,

dismiss the controversy bleeding the more entangled

by your hearing.

Menenius equates the tribune's pronouncements with images of noisy, bloody, diarrhetic, moaning, bowel movements and "pinched" rectums bringing the ass image to the tribunes in sick and sickening detail.

26. Hunt, "The Backward Voice of Coriolanus."

27. Ibid. 
Hunt points out that Menenius answers the people with his own ass talk-he breaks wind - when he relates the fable of the belly to the people. ${ }^{28}$

\subsubsection{1-76}

Menenius - Sir, I shall tell you. With a kind of smile, Which ne'er came from the lungs, but even thus-For, look you, I may make the belly smile As well as speak.

Thus, Menenius's flatulent report is the belly's smiling answer. Though a patrician, he is not averse to bawdy scatological discourse. His time making asses of the, already asinine, tribunes ends abruptly, with insults sandwiched between niceties.

\subsubsection{1-94}

Menenius - God-den to

your worships: more of your conversation would

infect my brain, being the herdsmen of the beastly

plebeians: I will be bold to take my leave of you.

He puts down the commoners/tribunes most clearly. However, much of his disparaging comments could be applied to himself: he literally talks out of his ass. Menenius also shows how swayable he is to the political winds when he sheepishly defers to the tribunes following Coriolanus's banishment.

Volumnia brings news that Marcius (Coriolanus) is coming home, and has sent Menenius a letter. The news gives him "an estate of seven years' health; in which time I will make a lip at the physician" (2.1.112-114). Menenius obviously loves Marcius, while for Volumnia there is no dialogue that indicates she loves her son at all. Menenius when discussing Marcius, always talks honestly and from the heart without any of his frequent patrician churlishness.

\section{Tribunes}

The tribunes merit no swearing, poetry, humor, or dramatic imagery of any kind. They are penned in the style perceived by Coriolanus and Menenius: petty, two-faced, conniving, asinine scoundrels. Menenius brought up their bloody, noisy, bowel movements and other "anus" related allusions, but even without his insights, the tribunes would still come off as reprehensible asses worthy only of contempt. They are more concerned with preserving their own

28. Ibid. 
office and power, than serving the people..$^{29}$ They try to manipulate the people to initially deny Coriolanus the consulship, but that failing, they have the people - the multi-headed beast-recant their approval, then ape the tribunes' verdict of banishment. Had Rome been sacked, the tribunes were looking at "death by inches" (5.4.40).

\section{Conclusion}

Coriolanus is clearly his own worse enemy. His words unseat him time and time again when enraged. Volumnia says he is too absolute, as does Aufidius, but he was made so by her Roman precepts: Chernaik shows that man/play are "obsessively concerned with Roman values." ${ }^{30}$ Menenius - who loves Coriolanus deeply - is much closer to the truth, saying he is too noble for the [Roman] world (3.1.320-325). Coriolanus's strict adherence to such values, combined with his contemptuous rage, left him open to Volumnia's frequent manipulations as well as those of the tribunes and Aufidius. Volumnia buried many emotional Trojan horses in her son, though whether by conscious design is unknown.

Volumnia and Menenius are unashamedly duplicitous-as are the tribunes and Aufidius. They are concerned about how they are perceived and their own longevity and prosperity: not so for Coriolanus. Truth and honor are his meat. As stated-honestly without intent to beguile - to an unnamed patrician by Menenius, "His heart's his mouth: What his breast forges, that his tongue must vent;" and his anger makes him forget the name of death (3.1.320-325) - not desirable traits for a politician. That does not mean he does not understand politics-Leggatt feels that Coriolanus grasps political realities better than the tribunes or Menenius. ${ }^{31} \mathrm{He}$ does seem to be as Goddard termed him: an "incorrigible truth-teller"32 not at all politically correct. Moreover, his fear of words and unbending will to play the man he is are ill suited for the political arena which he is thrust into.

Coriolanus's nobility and godlike powers cause the expected envy and hatred that follow anyone stationed far above the norm. Falstaff stands in dark contrast to Coriolanus. Though a knave through and through, Falstaff's lies and boasts bring smiles, while Coriolanus's Roman work ethic and lack of

29. Alexander Leggatt, Shakespeare's Political Drama (London: Routledge, 1988): $197 \& 201$.

30. Warren Chernaik, The Myth of Rome in Shakespeare and His Contemporaries (Cambridge: Cambridge University Press, 2011).

31. Leggatt, Shakespeare's Political Drama.

32. Goddard, The Meaning of Shakespeare, 210, 219-225. 
boasting (2.2.89-91) endear him to few. Falstaff is loved by audiences and, for a time at least, by prince Hal. Falstaff's boasts are lies, and he is ever greedy in physical and material pursuits, while Coriolanus, though entitled to do so, avoids boasting and kicks at spoils. Coriolanus's one instance of boasting is done to incite the mob to end his life (5.6.130-135).

Before his banishment, Volumnia repeatedly advises him to not state his true feelings until doing so would have no repercussions (3.2.23-27, 51-57, 60-65, $67-84$, \& 89-103), to say words not from his heart, but "bastards and syllables of no allowance to your bosom's truth" (3.2.71-72). She also instructs him on how to move the people without words-just hold your hat in your hands "Thy knee bussing the stones--for in such business Action is eloquence" (3.2.92-93). Volumnia's eloquence is-not surprisingly-to deceive and manipulate. Menenius assures Coriolanus - based on experience no doubt - that her tactics will win the commoners' hearts.

Coriolanus will kneel, but not to placate the commoners, but to his wife and mother in the intercession scene (5.3). He shows his true feelings with no intent to manipulate-his eloquence is void of artifice. Volumnia then kneels and has the other supplicants kneel, but only as a gesture from her bag of theatrical tricks to shame her son to do as she desires. That her victory ensures his death matters not a whit to her.

Coriolanus had merely to speak a word, and he would have become consul, the most powerful position in the world. Later a word again would have been enough for him to destroy Rome with his Volscian army. His words are rooted in his heart. He admits that he would flee from words, preferring swordplay to rhetoric (2.2.84). That is not to say he can't speak movingly; he does so when rallying his troops after Corioli (1.6), and presenting his neck to Aufidius (4.5), and with wit while pleading for the commoners voices (2.3) and with Aufidius's servants (4.5). He does speak, actually begs, but not for riches, power, or revenge, but for the freedom of a poor man in Corioli who used him kindly (1.9.93). Cominius says "O, well begg'd!" to make sure the supposed haughty proud patrician Mars begging for a poor man's freedom in a foreign city does not go unnoticed.

Following the successful intercession, Volumnia enters Rome as its patroness amidst great fanfare showered with flower petals; her son had done so three times for his martial valor - Volumnia for her own gain. She believes her verbose speech and "eloquent" actions swayed her son's heart to give his life up for her. Goddard argues convincingly that the presence of Virgilia moved the immovable warrior, not Volumnia ${ }^{33}$-Coriolanus was not following his mother's counsel after 3.2. Volumnia's triumph is even more depraved in such context.

33. Ibid. 
Coriolanus does not sack Rome, though a word or gesture would have seen the act done. His love of family releases "his pity jailed by his injury" (5.1.76-77) received by the hands of the city he served so selflessly. Love breaks down the oppressive virtuous Roman precepts he had been shrouded in. Rome and his family will not know the horrors of war, though such pity, he knows, will be "most mortal to him" (5.3.206). His greatest victory is not bound by any battlefield, but alone in his own sphere where love triumphed over his unyielding honor and hate. Coriolanus was like an immutable force, a god, throughout the play, but he did succumb in the end. The dove vanquishes the eagle after all (5.3.29 \& 5.6.133). It is fitting the Roman poet Virgil writes the epitaph: love conquers all.

\section{Bibliography}

Bradley, Andrew Cecil. Shakespearean Tragedy: Lectures on Hamlet, Othello, King Lear, Macbeth. London: Macmillan, [2 ${ }^{\text {nd }}$ ed.].

Burke, Kenneth. "Coriolanus - and the Delights of Faction." The Hudson Review 19, no. 2 (1966): 185-202.

Campbell, Oscar James. Shakespeare's Satire. New York: Gordian Press, 1971, [2 $2^{\text {nd }}$ ed. $]$.

Chernaik, Warren. The Myth of Rome in Shakespeare and His Contemporaries. Cambridge: Cambridge University Press, 2011.

Cook, Judith. Shakespeare's Players. London: Harrap Limited, 1985, [2 ${ }^{\text {nd }}$ ed.].

Curry, Julian. Shakespeare on Stage. London: Nick Hern Books, 2010.

Dennis, John. The Critical Works of John Dennis, Edited by Edward Niles Hooker. Baltimore: Johns Hopkins Press, 1943.

Goddard, Harold. The Meaning of Shakespeare, vol. 2. Chicago: Chicago University Press, 1960, [2 $2^{\text {nd }}$ ed.].

Gross, John. After Shakespeare, Edited by John Gross. Oxford: Oxford University Press, 2002.

Hellpern, John. "Shakespeare's Least-Loved Play; But This Coriolanus Stands Apart." Observer. Last modified February 28, 2005. goo.gl/Z6UpBF.

Humphrey, Robert. "Fatherly Mothering: Masculine Volumnia, a Martial Political Woman." The Artifice. Last modified April 9, 2014. goo.gl/RrgUUV.

Hunt, Maurice. "The Backward Voice of Coriolanus." Shakespeare Studies 32 (2004): 220-239.

Knight, George. The imperial theme: further interpretations of Shakespeare's tragedies including the Roman plays. London: Methuen, 1954.

Leggatt, Alexander. Shakespeare's Political Drama. London: Routledge, 1988.

Lewis, Wyndham. The Lion and the Fox. London: Grant Richards, 1927. 
Maune, John. "Topsy-Turvy and Other Carnivalesque Aspects in Coriolanus." Athens Journal of Philology 3, no. 1 (2016): 23-38.

Palmer, John. Political Characters of Shakespeare. London: Macmillan, 1961, [6 ${ }^{\text {th }}$ ed.].

Putney, Rufus. "Volumnia." In Twentieth Century Interpretations of Coriolanus, edited by James Phillips. London: Prentice Hall, 1970, [1 $1^{\text {st }}$ ed.].

Ripley, John. Coriolanus on Stage in England and America, 1609-1994. Cranbury, N.J.: Associated University Presses, 1998.

Shakespeare, William. Coriolanus, Edited by Kenneth Deighton. London: Macmillan, 1900. Shakespeare Online. Accessed February 20, 2010. goo.gl/ xJo6Q4.

Shaw, George Bernard. Man and Superman. Cambridge, Mass.: The University Press, 1903.

Swinburne, Algernon Charles. A study of Shakespeare. London: Chatto \& Windus, $1880,\left[2^{\text {nd }}\right.$ ed. $]$. 
